\title{
VERSITA
}

\section{ACADEMIC LIFE}

\section{The Uniting of Europe: A Memoir of Ernst B. Haas}

\section{David Laitin}

Stanford University

I am talking about my former teacher Ernst Haas, a great scholar, Europeanist. He was born in Germany in 1924, in Frankfurt to a very secular home and like many secular Jews in Germany and in Eastern Europe at that time, was profoundly anti-Zionist. He believed in a cosmopolitan world, a world in which many people of different ethnic groups, of different races, could live together in the same state. When I was still a student, I used to joke with him that he was an anti-Zionist because he had a love for Chinese food and you could not get good Chinese food in Israel, but at Berkeley you could. He was a cosmopolitan like many of the Eastern Europeans who had to flee from Nazi Germany. His family escaped to the U.S. in 1938, just before the war. He served in the U.S. Army during the Second World War and then went to graduate school in Columbia University, where some of the great scholars of his time were studying international relations. He had had no idea where Berkeley was but that was the only offer he got. He travelled across the country to California with his wife and never left. His dissertation was on the contradictions and difficulties of balance of power theory which was a big theory of its time in the realist tradition, and he felt great inadequacies in that theory, which led him into new directions. But this paper is not an analysis so much of his work, although I will do that, but more of a "memoir".

I came to Berkeley as a Ph.D. student in 1967 and took several courses from Haas - in International Relations Theory, his great course in Nationalism and Imperialism, and, of course, the course for which the uniting of Europe was the foundation of-Regional Integration Theory. He was the co-advisor for my doctoral dissertation Politics, Language, and Thought: The Somali Experience. I was really writing about African nationalism, and why, in African nationalism, unlike, say, in Estonian nationalism, national language did not play a role in the independence movements. They continued to use the languages of the colonial power and I was interested in what constrained these African states from 
reviving and developing their indigenous languages. Haas knew nothing about Somalia and nothing about language but he was the most intellectually rigorous person I met at Berkeley and I urged him to advise me on my dissertation along with the political theorist Hanna Pitkin, who wrote on Wittgensteinian language. Altogether I think I got great advice from people who could not find Somalia on the map. Haas became a close family friend, he took my young children to the choo-choo trains in the Tilden Park overlooking Berkeley, so our relationship was much more than an academic and student — we became close family friends over the years.

Uniting of Europe, a book that he published in 1958, was a book that was narrowly empirical. It was about the development of Europe in the European Coal and Steel Community. In 1964, he published a book on the International Labor Organization called Beyond the Nation-State: Functionalism \& International Organization. These two books, although they were narrowly empirical, studying each just one organization, had extremely broad theoretical ramifications in the development of what became to be known neo-functionalism. This short paper will place this Haas' neo-functionalist theory to help understand the sources of international peace and the future of Europe. So it really had very great ambitions, these books, theoretically, and that is to understand the sources of peace and the future of the nation state.

\section{Neo-functionalism vs. Realism}

Well, what is neo-functionalism? That is what this paper is about. All international relations scholars in the 1940s and the 1950s were basically focused on a single question - how can we avoid the third world war, a war which was likely to bring nuclear holocaust? Or, how to construct peace? And the dominant approach at that time was led by Hans Morgenthau in the U.S., University of Chicago, a German emigree, and Hedley Bull in the U.K.

Haas, as I mentioned above, was sought to show that their big ideas that power had to be balanced against power. And if power was balanced against power, no one would have an incentive to attack. But if the powers were imbalanced then the stronger party could take advantage of the weaker one, attack and thereby start a war which in the world of 1940s and 1950s would be of devastating consequences for all. But Haas felt that this notion of power balancing was incoherent - it did not explain why a country would go to war. For example, if one power were weaker, why would it just not surrender rather than fight? 
So what were the conditions under which a balancing would bring peace? And could it assure peace if an arms race develops, both sides of the power balance would get more and more ability to destroy the world? That did not seem like a very good prescription for peace.

For Ernst Haas, the key was to how nations could build international institutions to build new institutions and by so doing, relinquishing their authority over their own populations by their own free will. Why would they do this? Haas was not an idealist - he did not believe that people acted in a way to bring everybody happiness. They act in a way to bring themselves happiness. But sometimes when you have to bring yourself happiness, you bring the worst consequences for everybody else. So he did not believe that everybody was nice and if we only realized that everybody was nice, the world would be safe. He believed people were self-interested. And so the idea was: how to build a system of institutions where states would be self-constrained-self-constrained from destroying each other. And for Ernst Haas, functionalism was that key.

So functionalism from the point of view of David Mitrany and many of the architects of European Union - the great architects of European Union were functionalists - was something like the following: You get countries to trade with one another and eliminate tariffs so trade gets greater and greater and more complex. And your mutual benefits, because more trade brings greater growth and greater consumption, with mutual benefits comes cooperation and unity. So a world in which people are connected through trade will bring a world in which people cooperate and will have no reason to go to war, because war would eliminate all this nice trade. And because of this trade people would feel like one another and the more and more they felt like one another, the more they would become unified. This was the idea behind the architects of the EU.

Haas did not believe that. Haas did not believe that trade would bring happiness and peace on its own. Why not? Because in the late $19^{\text {th }}$ century it was the period of the greatest expansion of world trade and in 1914 nobody would believe there would be a war that lasted that long and be so horrifying. It was the world in which Europe was so completely connected through trade and one in which Europe broke down in costly warfare.

Haas's idea built on functionalism, but with a major change. He believed that trade complimentarities not only brought, as functionalists said, some benefits but also some costly conflicts. That is to say, if country A trades with country $\mathrm{B}$, and country B's automobile industry is suddenly out of business because country A produces better cars, country B is going to be pressured by its own 
interest groups to raise tariffs, to hold back trade from country A, to do whatever it could to keep the better cars away from their own consumers. And trade often brings other issues, for example, that contracts between countries could lead to a sense that the products being sent by these contracts were not of the highest quality and the country B wants to sue country A, not country A but the firms of country A, for not fulfilling its contract. But the courts in country A support the firms of country A. All these trade conflicts come out of increased trade. So it is not like everybody is happy with increased trade but there are losers with increased trade. But costly conflicts, Haas argued, lead to institutions that are created to resolve those conflicts at lower cost than fighting. And if the trading countries build institutions to resolve conflicts, the conflicting parties will tend to go to the place where these institutions sit-Strasbourg or Brussels. They move to where the conflicts are resolved because that is where the political community can determine who wins a trade war.

The institutions create new demands, because people are coming to Strasbourg for the European Coal and Steel Community or Brussels for the European Union. They are coming there as lobbyists, they are coming there as lawyers and they are demanding more and more protections. That means you need better courts, and with better courts you need more lawyers and judges. If you need more judges, you have to have an institution which certifies a judge as suitable for Europe and not just for France or Germany. The more there is this kind of pressure and the more there is this kind of fighting for one's own interests, the more institutions get created. And Haas called this process "spill-over".

With the creation of new institutions with new powers and as you get institutional complexity, you get what Haas calls a change in the locus of authority. More and more people are seeking resources for their own interests, for their own self-protection. They are moving from the capital of their country to the capital of their regional organization-i.e. lobbyists moving from Bonn to Strasbourg, because allocative decisions are being made there. And as you get a change in the locus of authority, from Bonn or from Paris to Strasbourg or to Brussels, you get the origins of a new political unity, a new political centre.

So self-interest creates conflict, conflict which leads to new institutions, new institutions create demands for every new institutions - that is the "spill-over" factor. And with "spill-over" you get the change in a locus of authority and political unity. It is not love for each other but desire to defeat one another in political allocated decisions, which drives political unity. It is not human goodness, but human self-interest which is behind the neo-functionalist theory. 


\section{Neo-Functionalism vs. Transactions: The Hare and the Tortoise}

When Haas was writing this at Berkeley, on the other side of the continent there was a scholar of his own school about political unity_Karl Deutsch.

Karl Deutsch was born in Prague in 1912 and taught in Yale and then in Harvard and created a counter-school to the study of Europe and there was often a war among the U.S. international relations students between the students of Haas and the students of Karl Deutsch. My college roommate was a student of Karl Deutsch so we had our own little war across the continent. Karl Deutsch's theory was sometimes called the Transactions Theory. And if Haas, to use the pun, was known as the hare-that is, institutions would quickly invent a new political unity - then Deutsch was a tortoise. He saw a cultural and political change as taking centuries and not decades. His central idea was that trade would bring higher rates of communication. The more communication - and that is the more people having to bargain together, having set conditions to their trade - the more they would begin to share culture.

So what Deutsch's students did was quite interesting. We are not living in the world of first-class mail anymore, but they would take all first-class mail deliveries of the international postal union and count the probability for someone who lived in Marseilles to send a letter elsewhere in France as opposed to Italy or Germany. The extent to which people put most of their stamps for first-class letters to their own country meant that communications to their own country were much more probable than elsewhere, say, to Europe. He had the students measure changes in the ratio of letters from any country in Europe for within country as a percentage of all letters sent. And what he argued was that over the course of the 1950s and 1960s, this ratio did not change. There was not a development of European culture or European community, that there was still a national community - people were much more likely to write letters to people within the boundaries of their own country than within the boundaries of Europe. But he found, in the course of hundreds of years, over the course of Europe that the people of Marseilles, who spoke Provençal, did in fact become a part of France speaking the language of Île-de-France, and that it was a development of a French community from a zone centuries earlier of many-many different languages. So he studied the origins of political community and said they would take centuries.

However, as this communication between states arose or developed, Deutsch described the situation not as a new state but as a security community. The more 
Europeans traded with one another and communicated with one another, the probability that they would go to war would decrease. He said that compare, say, the situation of Germany and France in the 1870s to Canada and the United States in the 1990s. Nobody in the United States or Canada had any expectation that we would ever be at war with one another. Therefore they did not arm each other. So you crossed the border without seeing any military phobia. But in the 1870 s or in the 1860s in France and Germany, there was no expectations, there was no security community, there was no sense that peace was inevitable and there was preparation for war. And what Deutsch tried to show is the development not of a political unity but of a security community, one where is no expectation of war. And one of the interesting features for a non-European like myself looking at the crisis of Europe today is that for all the anger between, say, Spain and Germany or Italy and Germany, there is no way they are putting troops on each other's borders. There is a clear security community in Europe, which is a great success of the Union, even if Europe is in trouble.

So for neo-functionalism it took decades to create political unity, transactions theory takes centuries. Those security communities occur early in the process.

\section{Neo-Functionalism and the Third World}

Philippe Schmitter was a student of Ernst Haas in the 1960s and is now Professor Emeritus at the European University Institute in France. He was the founder of contemporary studies on "corporative" governance but when he was a graduate student and many years after he collaborated with Haas on regional organizations and the model of the EU, the Latin American Free Trade Association (LAFTA), the Economical Community of West African States (ECOWAS), the East African Community (EAC), the Caribbean Free Trade Association. Students were writing dissertations on these regional organizations in the 1960s and 1970s under Ernst Haas's direction.

The key prediction of Schmitter was that without a powerful community of interest group associations, there would be no transfer of authority, and thus no "spill-over". If you did not have modern interest in organizations, modern associations to go and lobby for the rights of Europe's members. If you did not have this associative network of organizations, in industry, in commerce, in labor, there would be no chance for "spill-over", because there would be no organizational presence at the new capital. And the key prediction was that there would not be "spill-over" with these associations, but rather he called it 
"spill-back". That the costs to certain groups of the integration would push them or urge their governments to pull out of these organizations, rather than suffer from the difficulties of paying the costs of going out of business because the other country is producing cars, or whatever, more cheaply. And in fact these predictions were basically right, that there was more "spill-back" and most of these associations have disappeared and look nothing like what the EU looks today.

In 1975, when I was writing my own dissertation, it was the year of "Eurosclerosis", and Haas declared, I think, prematurely, he would say before he died, that there was an "obsolescence of regional integration theory" (that was the title of his essay). And he said that because of what he saw as "Eurosclerosis" there would be no more "spill-over" just "spill-back", or another word Schmitter invented "spill-around", that is a whole bunch of associations but not leading to any greater degree of authority at the new centre.

\section{Haas vs. Intergovernmentalists}

Finally, Haas fought against not only transaction's theory but against a group of people who called themselves "intergovernmentalists". Haas believed the gigantic academic battles between the people who called themselves "supranationalists", who saw there was going to be a huge nation state, and those who were "intergovernmentalists", who saw the continuation of the nation state as it presently exists but were willing to make mutually beneficial treaties with other countries, never giving up any of their sovereignty (they were generating heat but not light). Andrew Moravcsik, who is now in Princeton University, is a major figure in this "intergovernmentalism". And Haas pretty much ignored these debates. He found these to be just battles between "brothers" than anything seriously predictive about Europe.

As a Haas's former student during that period, I argued in a paper that thinking of supranationalism in European Union to think of it as a development of a new France or the development of a new Germany was the wrong way to think about state development in the $20^{\text {th }}$ century and the $21^{\text {st }}$ century. That India was the model.

India was a $20^{\text {th }}$ century state and it had, in cultural terms, even though it was a coherent state, a 3+/- 1 language system. And everybody knew it and it brought unity to them in a multi-cultural, multi-lingual equilibrium. Everyone in India 
who had ambitions to have any good job opportunity needed to speak English. If you were going to listen to any of the newscasts or get around the country and needed to understand what was being announced at the train stations, you had to understand Hindi. That is two languages, and third, you had to learn the language of your own state. The average state's size in India is about 35-40 million people, so we are not talking about small places. So the state language Hindi, the national so-called cultural language, and English, the language of high administration and business. But if you were a minority in one of those states, say in the state of Karnataka, where Bangalore is, the state language is Kannada. But in the north there is a minority group of Marathis, they have a right for primary education in Marathi-that is $3+1$. That is what everyone in the Marathi areas of Karnataka needs to speak to have a full range of opportunities. But if you were in a state, say, in the north like Bihar, where the state language is Hindi, you only have to know English and Hindi for success, which is 3-1.

Europe is the same. It is only a 2+/-1 language system. If you are lucky and were born in England, you only have to know one language and you are fine. If you are in France, now, believe it or not for the French, you have to know English and French. That is two languages. But if you are in a region that is promoting themselves as having one of the new languages of Europe, let us say in Catalonia or the Basque country, you need to know Catalan, English and Spanish - the state language is Spanish, and the language of Europe is English. And everybody knows this system and I can come to Estonia and give a lecture in English and you are expected to understand me. So it is a 2+/-1 language system and everybody knows it and everybody knows what language to speak to whom they meet and, like India, this is a new cultural form, not of a single language or single state but of a language repertoire which everybody shares and everybody understands. And this is the kind of state that is being developed before our very eyes and whether it is intergovernmentalism or supranationalism, it is a development of a new state form.

\section{The Euro Crisis: A Haasian Perspective}

I want to say something about the Euro crisis from a Haasian perspective. It is too interesting to ignore and because, as a Haas's student, I felt that the Nobel Prize winning critic of the euro system, Paul Krugman, has been completely wrong about the issue. I want to show how a Haas's student looks at the euro crisis today. Krugman argued from the very beginning of the Maastricht Treaty 
and the development of the euro that the currency could not withstand an economic crisis without a strong central bank. He kept on saying that without something like the U.S. Federal Reserve System, which was entrusted with assuring outsiders that California or Minnesota or North Carolina could not go bankrupt and bankrupt the country they would be able to bail out any state from within the single currency with its own resources. The European Central Bank had no powers like the Fed. The currency could not withstand the economic crisis when one or two states went into fast bankruptcy. And countries could not be saved through devaluation, which is a normal way to get saved when a state goes near bankruptcy-you devalue your currency which is effectively telling your workforce that you're poor. And, therefore, making your own country more valuable for investors, because it is much cheaper. This is how Argentina got out of its crisis in 1998-1999. So the two forms of saving countries from crisis is that it is being bailed out by a central authority or by devaluation which was prevented by Maastricht and therefore, Krugman said, the euro could not survive.

Haas's new preface, which I urge you to read if you're interested in this subject, for the last edition of the Uniting of Europe, written before Haas died in late 2003 (just about one or two weeks after he finished writing this preface), he revealed no understanding of the European macro-economy or of euro. There is no mention of euro as if it had anything to do with the uniting of Europe. It is an astonishing gap in his work, he had no understanding of economics, he was really a sociologist. But as a Haas's student I can use the crisis to think about the insight or even confirm the theory, the neo-functionalist theory, by looking at what has been happening in Europe in the last year or so.

So, the first thing a Haas's student would say is that there is no way that in 1992 something like the U.S. Fed could have been established. You do not build new institutions from sovereign states. Sovereign states, and certainly the Bundesbank in Germany, would not give up that much authority. It was no way to do it. So what you did is you created the euro and expected that everything would be fine, until crisis hit and then you would have to deal with the crisis later. So, by building the minimal institution, like the European Coal and Steel Community, we did not solve any great problems.

What was the beginning of institutional development was really the approach of the creators of the euro. But the crisis of 2008 and 2009 forced the coalition, called in France "Merkozy" (Merkel and Sarkozy) to allow the ECB to grow in authority. Why did they allow it? Because they were nice to Greece? They could not give a damn about Greece. Why did they give the ECB the authority 
to bail Greece out? They did so, because German banks had loaned so much money to Greeks that the German banks would go bankrupt unless there was a guarantee of Greek loans by Europe. So what the Germans were doing was actually subsidizing their own banks by giving greater authority to the European Central Bank. There is the key to neo-functionalism. They did not do it because they were nice, they did it because the cost of not doing it would be worse. For your own domestic coalitions. As the ECB grew in authority to bail out of the southern tier of the euro zone, it was becoming the institution that Krugman saw as necessary for euro-survival. This is the neo-functionalist "spill-over" that the crisis has brought greater centralization of institutions rather than its collapse, because the costs of breaking them down were higher for the domestic actors than they were for propping them up.

This deep conflict within the EU (north vs. south) - did it bring war? No. Did it bring anger? Yes. Did it bring politics continuously, and this politics of continually meeting to create institutions to solve the problem was the "spillover" that Haas predicted in 1958. This is not to claim that the "spill-over" process is inevitable - it could spill back with populist leaders, like Grillo, riding waves of discontent with Eurocratic domination-but rather that as Haas presciently wrote, if a united Europe becomes a political reality, it will emerge from crises that are the result of incomplete institution-building through this process of "spill-over". So that is my view of what is going on in Europe today-against their own wishes and against their own personal feelings they are building stronger central institutions that are a reflection of a "spill-over" process.

\section{Questions}

I think Haas's strongest normative concern was one that said that (a) there cannot be another war and (b) we have to make Europe safe for minorities. And these international institutions from a normative point of view have been an incredible success. But then you can ask the other questions, normative questions - did this union have anything to do with the promotion of democracy? I think there is a great democratic loss if you look at Brussels today. And I think that some of the populist voting in Italy, which we just saw and continue to see, is a reaction to the immense failure of European leadership to deal in a coherent fashion with the 2008-2009 crisis. In a sense there was incompetence and lack of democracy and those are normative concerns that have to be, you might say, balanced with 
the incredible success that there are not German troops on the border of Greece or on the border of France, or French troops on the border of Italy, trying to protect national integrity with the populace movement to the south. So, in the sense of solving one great normative problem, he is subject to a normative criticism which you just raised.

\section{${ }^{*}$ About political unity}

So, in fairness to Haas, if you were to ask him what is the probability of political union through this "spill-over" process, he would say it is not very high, but yet, it is a possibility that would happen, as it were, inadvertently, so the political leaders would be the last to admit that there is anything called political unity or political unity on the agenda. They would be the last ones to admit it. Why? Because their constituencies are all national. And with Andy Moravcsik at Princeton I could give you a long list of the failures of constitution being one that becoming a member of European Parliament is a job called "exiled in France" than a job called "legislating" - that is where you send the countryfolk that you want get the heck out of the country rather than make law. The feelings that the regulations coming out of Brussels are increasingly alienating the European populace. All of these things are true. However, if you look at people at leading universities in Europe today, i.e. the next generation of leaders, they are planning their careers with Europe as their terrain. And I would bet, if I were to ask university students here or at Tartu, I bet if I were to ask them what is the probability that your first big job will be in Estonia? I would guess, the probability would be something like 0.5 . They will apply for jobs in Germany, they will apply for jobs in UK, they will apply for jobs anywhere in Europe that their skills allow and they feel free with that European passport to do that. That is - more and more young Europeans see Europe as their terrain and see their political leaders, whether it be Hollande or Cameron, as irrelevant to their own futures. There is a vast change coming from below that rules of Schengen are making possible the reconfigurations of people's life plans, which are based upon being members of Europe and I think this is happening despite the fact that these guys are negotiating. If you're talking to me about are holding back on banking union, holding back on financial union on issues which will be in the next, I would believe, in the next five or ten years will bring greater degrees of coordination in the union that exist today, because the banks of Europe cannot survive without coordination amongst them across the continent. So I would put the probability not very high for a political union but if you are going to look the world that is going to come, it is for young people who are making their life's choices based upon institutional possibilities that have already been created. 


\section{${ }^{*}$ About this being a particularly European phenomenon}

As I mentioned, I think Philippe Schmitter was correct about this. He took from Haas's theory the fact that with the European Coal and Steel Community more and more trade associations, which were "corporatist" or labor and business associations from the two countries and then with the EEC from the Inner Six countries, were brought to Strasbourg and then Brussels and thereby more and more authority was being centered there with very weak associational life in the Third World. Most of the associations were made in the capital city of their own country, demanding concessions from the cost they paid for being in an economic European community. So a typical example is in Tanzania being flooded with Kenyan goods or Grenada being flooded with Jamaican goods brought pressure in the islands or in the states for protection against the union rather than going to the union center, trying to get goods from that centre. And that's why Schmitter called this a "spill-back" process, because the efforts of the associations were to try to break the deals rather than to take advantage of them.

The assumption in Haas and Schmitter was that you had to have a really well-bureaucratized associational life that had the capabilities of sending representatives into the new center. And you could call the resources and the capacities of local interest groups in the Third World not sufficient to see that they could go to the centre and demand resources from it. But that has not very well worked out, it was just a prediction based upon the fact, not observing any interest group's activities in the new centers.

\section{* About the depth of crisis for a political unity to emerge and "spill-over effects"}

For the first question, there is no answer from the Haasian perspective. That is, if crisis gets deep enough, it may be too great for institutional response. And he had no theory of what that limit was. And you are perfectly right to say: "I can imagine a crisis such that..." the cost of institution-building are higher than breakup. And he had no theory. I am just giving an anecdote from his second great book Beyond the Nation State on the International Labor Organization, which didn't grow as much as he thought it would grow but will nonetheless give you a sense of how he thought about crisis.

So, early on in the process of forced labor Liberia took Portugal to the higher courts of the international Labor Organization for forced labor in Angola and Mozambique which were then part of the Portuguese empire. And ILO ruled with Liberia, and Liberia was like the star of the political left in the World for humiliating Portugal into changing its labor practices. So what did Portugal do? 
Portugal went to ILO and said, "There is forced labor in the Firestone rubber plants in Liberia." And Liberia, which had already accepted the authority of ILO by bringing the case, could not thumb its nose at the ILO and said, this is ridiculous, we refuse to be judged, and the ILO ruled against Firestone and Liberia. So, in a sense, crisis, that is the anger of Liberia against Portuguese imperialism and the anger of Portugal for being brought up by ILO, by Liberia, brought a stronger review process, a stronger institution of ILO because the cases were being brought to it, which were being accepted. So this is an example of, even under conditions of considerable anger, you can get, so to say end authority in a new centre.

As to the second question, I think there is a reasonable probability, after this recent election in Italy, that this process will turn back, or "spill" back. Haas, in the 1970s, thought that this could happen. I claim that this process is inevitable. However, what is interesting is Merkel, who started off this whole process after 2008 , has wanting to make Greece pay an enormous cost for all the whining that it did and the cooking of the books that it did. Merkel, in my judgment, as most of the German electorate today, wanted Greece to pay a cost for its bad behavior. And if it meant getting Greece out of the euro- "Who cares? Those Greek deserve it." This is, I believe, the common view of most voters in Germany. But Merkel, even though she tries to speak, especially in election times, to the concerns of the German voter, has done everything she has been able to to save the euro despite the concerns and the desires of her own population. Because the Bundesbank and the leading German banks and a ton of other European institutions, for example, there is so much institutionalism riding on the euro for German leading institutions that she has worked mightily to save the euro against the wishes of her own population. So I would say, no, it is not inevitable. Merkel may want to cave in into the wishes of her own population but the fact that they are fighting so strongly against it, suggests that there's alogic to neofunctionalism that is holding back the populace's desires of the medium voters of these countries. I was speaking to some macro-economists advising Hollande and the basic answer they give is the cost of saving Greece, or even holding up Spain or Italy is tiny compared to the cost of bank failures in Germany and France, if they do not do it. So, in a sense the integration process has made it immensely costly for the elite to let Greece go.

Would you compare the cost that Kohl paid to integrate East Germany to where it would be to save Italy? The word I get is Germany paid far more? Far more for political unity with East Germany than they would have to pay for political unity in Europe. 
You know-yes, East Germany is Germans, but once the Germans in the west realized what kind of Germans they were bringing in, they realized they paid a heavy cost. But Kohl had an easier time to save the East Germans that Merkel would have to save Italians.

\section{*About European identity}

I will argue, and I have always argued that people have multiple identities. And that we activate different identities at different times, whether they be local, urban identities, regional identities, national identities and religious identities. And at different times of your life you activate what I call your identity repertoire. And the question is really - are there European identities which were only, you could say, theoretic in 1945. Are they becoming activated in more and more parts of your life, such that your sense that you are European is that you are conditioning your behavior on the fact that you are a European. Rather than, say, an Estonian or rather than, a Balt, or whatever. My sense is, just to give an example, when I was here in the early 1990 s - there was a very-very clear sense that there was a thing called Baltic identity, which made Lithuania, Estonia and Latvia a common identity. And that was activated, I think, under Soviet rule. I have not seen anybody thinking of Latvia, Lithuania and Estonia a natural grouping anymore. Maybe there exists some but not a whole lot. It is not that it could not be activated under the circumstances but it is not a relevant identity, because there is no union of Baltic states, there is no common language of Baltic states and there are no special trade agreements or educational agreements or anything that make "Balticness" something crucial to you. But, when you have something like an Erasmus programme, or Schengen, or something then suddenly you start thinking of Europe as your terrain.

One of the happiest, it is irrelevant I think, but one of the happiest moments of my many years living in Europe was being asked to give a lecture in the Juan March Institute in Madrid, I was living in Paris. And I got on the plane at Orly, off the plane in Barajas airport, walked straight to the metro, and went to my hotel. I did not see a government official. I had chills, I was so happy. It was like going from Cleveland to Chicago. And in a sense, the fact that you could do this, without having to go to a money changing machine, without having to pay $15 \%$ to get francs changed into pesetas, was terrific and made me feel like the trip from Paris to Madrid was not crossing a border. It made me feel that they were both part of the same union.

So, in a sense, one's identity repertoire can stay the same, but the activation of the European identity is made much more likely with things like Schengen, with 
things like the euro, with the common passport regime. It makes that European identity more activated in more circumstances of life. And therefore there is an identity change in terms of the percentage of time that identity is activated, made relevant for your choices in life. So, it existed before, but it is much more relevant today.

\section{${ }^{*}$ About the application of Haasian theory to Asia vs to Europe}

So, a student of Karl Deutsch, whom I mentioned before, my own university roommate Peter Katzenstein, in a book called $A$ World of Regions: Asia and Europe in the American Imperium, tried to answer the question, why has Asia not had the same set of institutions as Europe. Why is [it that] our all agreements in Asia [are] intergovernmental, with no sort of centre, administrative centre, where officials from Asian countries meet and for which there are bureaucrats whose whole career is based upon administering the treaties, that is, there is no, you could call it, regional centre in Asia for which there are full-time career bureaucrats working for which interest groups from the Asian countries will send representatives. And he tries to address the question of why you are getting this different regional development in Asia from Europe. But I must confess, I didnot understand why, even reading the book, why you get this different outcome, but this is something for future research, because the future of Asia and Asian region is in doubt and you do not even have in Asia a security community as you do in Europe. The possibility of armed conflict is above zero when it comes to Japan and China, for example, the chances of armed conflict is way above zero when it comes to Taiwan and the People's Republic and the civil wars in Philippines and Mindanao have no direct concern, I say, that the wars of Kosovo did in Europe. But the wars in Mindanao are not a regional phenomenon in Asia, so there is not a kind of regional consciousness where regional solutions are taken in concert. And this is a big difference in Europe but I think that has not been explained theoretically.

\section{${ }^{*}$ About the boundaries of Europe}

My current research deals with some of this, on this issue. I'm fascinated by the deep and binding opposition of the Inner Six against Turkish membership and the sense that the last bit of unity of Europe would be undermined by bringing in a majority Muslim state. So it is a union of Christian heritage societies, which you are not allowed to say, but what you all think, although Jacques Chirac said it. And so, there is a clear sense of where the boundaries are or will we see whether Albania really joins the Union, which I think is majority Muslim - there 
may be a crack in that armor. So there is a belief, it stops somewhere going East. I cannot imagine Russia ever being a part of the European Union, and I thought some years ago that Ukraine was a natural, but it seems not to be. Maybe because its current circumstances are the same than in Belarus. So, in a sense there is ambiguous eastern boundary to Europe - it is clear that the boundary excludes Turkey but it is not clear about, say, Ukraine if its political arrangements ever become more transparent and democratic. So the boundary issue is a very-very deep and complex one. Haas believed that the expansion east was going to stop this "spill-over" process. Even for the Baltic, he felt that the more you expanded the boundaries, the less you would be able to develop institutions, because you have to keep on making private bargains with new countries coming in, that had not fully accepted and gotten through these processes of development. And he saw that, in his last essay, he saw that it is a threat to "spill-over". And I think that the more Europe expands to the east, the more it will look like an association of states rather than a possible new political union.

\section{${ }^{*}$ About external financing of Europe}

I completely agree. I only add one small element to it, and that is that after the Second World War there was an extremely rich country that bribed the Europeans into doing this. Happened to be my country, but the bribe sum was immense, and then shows that those guys who were functionalists that whole group, they chose all those economies who had this crazy idea that there could be a united Europe, and basically said, if you write up common economical plans, we will throw more money at you that you have ever seen before. And without this American jumpstart it could not have happened. But I agree entirely, the American jumpstart was based upon the view that Germany was too big for Europe and that you had to contain Germany. And the only way to contain Germany was making it part of a larger group which would be, in a sense, selfconstraining. And that, without that the process of "spill-over" would never have started. Why this did not happen in Asia? I think because you could not get Japan and China after the Second World War to be the Germany and France. Because the American-supported dictatorship of China had just fallen.

David D. Laitin is Professor of Political Science at the Stanford University. Since 1996 he is elected member of the American Academy of Arts and Science and since 1997 member of the National Academy of Sciences. He received his BA from Swarthmore College and his $\mathrm{PhD}$ in political science from UC Berkeley, working under the direction of Ernst Haas and Hanna Pitkin. Over his career, as a student of comparative politics, he has conducted 
field research in Somalia, Yorubaland (Nigeria), Catalonia (Spain) and Estonia, focusing on issues of language and religion, and how these cultural phenomena link nation to state. Over the past two decades, mostly in collaboration with James Fearon (UC Berkeley), he has published several papers and books on ethnicity, ethnic cooperation, the sources of civil war, and on policies that work to settle civil wars. The (total of 14) research articles published by David D. Laitin with James Fearon, based on the short bibliometric analysis, has been cited 4,000 times during the past twelve years (2001-2012) and one of these'Ethnicity, insurgency, and civil war' in American Political Science Review (vol. 97, no. 1, 2003), has been cited 3,437 times (May 15, 2013). 